\title{
Strukturalisme: et romantisk prosjekt?
}

\section{Structuralism - A Romantic Project?}

\section{Otto Martin Christensen}

\begin{abstract}
The author examines the relationship between the aesthetics of Romanticism and theories developed within the $20^{\text {th }}$ century structuralist tradition. In the first part of the article he shows that there are affinities between the broad Romantic concept of the unifying symbol and the way linguistic entities are considered as self-contained units within certain theories of classical structuralism. In the last part he shows how poststructuralism tends to focus on rhetorical devices that display disruption rather than integration and unity, theorists such as Paul de Man taking a philosophical stance that amplifies the rupture between man - as a creature that allegedly relates to reality exclusively through linguistic means - and a multifaceted world that, according to the author, deserves better.
\end{abstract}

\section{Keywords}

structuralism, poststructuralism, Romanticism, symbol, allegory, irony 
Den strukturalistiske tradisjonen var en sentral strømning i det 20. århundres tenkning, hvor den bidro med viktige teoretiske tilskudd innen en rekke human- og samfunnsvitenskapelige fagområder. Representanter for både den „klassiske“ strukturalismen og poststrukturalismen (særlig sistnevnte) hevdet å frembringe grunnleggende nye perspektiver på språk, kunst, kultur og samfunn. I egne øyne brøt man altså radikalt med fortiden. Med utsikt fra det 21. århundret vil man imidlertid kunne stille spørsmål ved en slik selvforståelse. I denne artikkelen vil jeg gjøre nettopp dette, ved å undersøke hvorvidt man innenfor den strukturalistiske tradisjonen trekker veksler på elementer i det romantiske kunstsynet.

\section{Imitasjon, harmoni, ekspresjon}

Tråden som går fra romantikken til strukturalismen og dens post-varianter kan vi begynne å nøste opp ved å gå inn i enkelte temaer innen det man gjerne kaller den ,preromantiske" estetikken.

Det mimetiske kunstsynet hadde mange talsmenn på 1700-tallet. I noen grad representerte det en forlengelse av den franske klassisismens kunstsyn. Men idet man fremhevet at kunsten ikke skulle imitere naturen via forbilledlige eksempler fra antikken, slik man hevdet i klassisismen, distanserte man seg kritisk fra klassisismens idéer. Normene skulle hentes direkte fra naturen, hevdet mange, og ikke fra tradisjonen. Denne estetiske nyorienteringen inngår i opplysningstidens allmenne tradisjonsoppgjør, et oppgjør som blir til et konstituerende trekk ved moderniteten. Men naturbegrepet blir gitt svært ulikt innhold av de enkelte teoretikerne, og dersom man ikke primært knytter begrepet til kunstnerens „indre natur“, medfører ikke utviklingen med nødvendighet et brudd med det mimetiske kunstsynet. Dette er bl.a. den berømte traktaten til Charles Batteux fra 1746 - Les Beaux-arts réduits à un même principe - et eksempel på. Det mimetiske prinsippet er imidlertid ikke enerådende på 1700-tallet. Det konkurrerer både med et ekspressivt prinsipp og et harmoni-prinsipp, hvor det sistnevnte - i likhet med det mimetiske prinsippet - går helt tilbake til den greske antikken. La oss se på hvordan forholdet mellom disse tre prinsippene utvikler seg frem mot romantikken.

Hva angår harmoni-prinsippet, er det helt fra pythagoréernes dager knyttet til det skjønne. Panofsky definerer sammenhengen på følgende måte: „Beauty is the harmony of the parts in relation to each other and to the whole". ${ }^{1}$ I og med at man fra renessansen hadde tendert til å la harmoni-prinsippet tjene som et supplement til det overordnede mimetiske prinsippet (i den forstand at man innenfor de bildende kunstenes teori krevet at kunstneren skulle forskjønne den naturen som ble gjengitt), var sammenhengen mellom skjønnhet og harmoni slett ikke ukjent på 1700-tallet. Dette er bl.a. Diderots kunstteoretiske tekster et eksempel på. Han skriver flere steder at det å oppleve skjønnhet er det samme som å oppfatte sammenhenger $(\text { rapports })^{2}$, og disse sammenhengene defineres

1 PANOFSKY, Erwin: The Life and Art of Albrecht Dürer. Princeton, New Jersey, 1955, s. 261.

2 Se for eksempel Diderots artikkel „Beau“ i L'Encyclopédie, hvor man bl.a. kan lese følgende: „La perception des rapports est donc le fondement du beau; c'est donc la perception des rapports qu'on a désignée dans les langues sous une infinité de noms différens, qui tous n'indiquent que différentes sortes de beau“. 
eksplisitt som sammenhenger mellom kunstverkets enkelte deler. Men samtidig ser det ut som om kunstverket i Diderots øyne er underlagt to prinsipper samtidig, slik det også var for renessansens kunstteoretikere, som nettopp nevnt: På den ene siden imitasjonsprinsippet, som angår relasjonen mellom kunstverket og den verden som ligger utenfor verket selv, og på den andre siden harmoni-prinsippet, som angår verk-interne relasjoner.

Karl Philipp Moritz' skrifter kan tjene til å illustrere hvordan harmoni-prinsippet for alvor kommer på offensiven. Dette skjer ved at imitasjons-prinsippet, etter mønster av Lord Shaftesbury, gis et nytt innhold. ${ }^{3}$ Ifølge Moritz imiterer ikke kunstneren den allerede skapte naturen, men gjennom sin skaperakt imiterer han selve skapelses-prosessen: Kunstneren imiterer ikke natura naturata, men natura naturans. Denne guddommeliggjøringen av kunstneren - som blir forberedt allerede i enkelte renessansetekster ${ }^{4}$, men som for alvor blir synlig i løpet av 1700-tallet - er et tegn på at man i kunstteorien flytter fokus. Man er ikke lenger primært opptatt av relasjonen mellom kunstverket og den ytre naturen, men relasjonen mellom kunstverket og kunstneren.

I forlengelsen av dette får naturlig nok det ekspressive prinsippet stadig større betydning, i den forstand at kunstverket begynner å bli ansett som et uttrykk for kunstnerens indre - men samtidig får harmoni-prinsippet en stadig større aktualitet (noe som foregripes allerede hos Lord Shaftesbury, slik det fremgår av sitatet i fotnote 3). For idet man begynner å anse kunstverket som et uttrykk for kunstnersubjektets indre, og idet dette indre samtidig etableres som noe unikt, blir det ikke lenger mulig å operere med universelle estetiske normer; og de som ikke oppgir det normative prosjektet fullstendig forsøker isteden å forankre normene i kunstverket selv, uavhengig av dets relasjoner både til den ytre og indre verden. Man fokuserer på relasjonene mellom kunstverkets enkelte deler og delenes relasjoner til helheten. Harmoni-prinsippet gis med dette en overordnet vurderingsteoretisk status. Moritz kobler således harmoni-prinsippet kun til verket som sådan, idet han kaller en av sine estetiske hovedtraktater for Versuch einer Vereinigung aller schönen Künste und Wissenschaften unter dem Begriff des in sich selbst Vollendeten (1785).

Moritz forsøker, som Batteux, å forene de skjønne kunstene under et overordnet prinsipp. Og på bakgrunn av den utviklingen som nettopp er beskrevet, griper han altså til harmoni-prinsippet. Hans poeng er at et kunstverk ikke har noe formål utover seg selv, slik andre gjenstander har. Kunstverket er slik sett fullstendig autonomt. Kunstneren må derfor bestrebe seg på å erstatte den ytre formålstjenligheten som finnes i bruksgjenstander med en indre formålstjenlighet - hvilket i praksis betyr at kunstverkets enkelte deler må gjøres samstemte i forhold til hverandre og til helheten. Han skriver (s. 153):

https://fr.wikisource.org/wiki/L'Encyclopédie/1re_édition/BEAU, lest 07.06.2016. Det er for øvrig 76 forekomser av termen rapports i denne artikkelen.

3 Se for eksempel følgende passasje i Lord Shaftesburys Soliloquy: Or, Advice to an Author fra 1710: „Such a Poet is indeed a second Maker; a just Prometheus, under Jove. Like that Sovereign Artist or universal Plastick Nature, he forms $a$ Whole, coherent and proportion'd in it-self, with due Subjection and Subordinacy of constituent Parts. The moral Artist (...) can thus imitate the Creator." http://oll.libertyfund.org/titles/811\#Shaft esbury_5987_360, lest 09.06.2016.

4 Bl.a. hos F. Zuccari og J. C. Scaliger, som i sin tur trakk veksler på antikkens forestilling om dikternes guddommelige inspirasjon, slik den er formidlet bl.a. gjennom Platons dialoger Ion og Faidros (selv om man blant Platon-fortolkere er uenig om Platons eget syn på denne forestillingen). 
Der allmälige Neigung der Gedanken gegen einander, oder die allmälige Verwandlung der äußeren Zweckmässigkeit in die innere, oder kürzer, das in sich selbst Vollendete, scheint daher der eigentlich leitende Zweck des Künstlers bei seinem Kunstwerke zu seyn. Der Künstler muß suchen, den Zweck, der in der Natur immer außer dem Gegenstande liegt, in den Gegenstand selbst zurckzuwälsen, und ihn dadurch in sich vollendet zu machen. Dann sehen wir ein Ganzes, wo wir sonst nichts als abzweckende Theile erblickten. ${ }^{5}$

Det fullendte kunstverket fremstår altså som en selvtilstrekkelig enhet, som noe som ikke peker ut over seg selv. Det kan slik sett defineres som en „intransitiv“ størrelse. Men mangelen på sammenheng mellom verket og verden utenfor verket kompenseres av den sterke graden av sammenheng som finnes innenfor verket: Det fullendte kunstverket er ikke bare intransitivt, det er i sin selvomsluttende karakter også preget av en maksimal grad av indre harmoni. Det fremstår som en organisk enhet - som et autonomt, men koherent system. Intransitivitet og koherens blir komplementære begreper (slik det blir i Saussures språkteori, slik vi skal se om en stund). Intransitivitets- og koherens-forestillingene blir konstituerende for romantikken, ikke minst den tyske.

\section{Symbolet}

Moritz kontrasterer sitt nye begrep om det fullendte kunstverket med „allegoriske“ kunstverk. Dermed forbereder han en dikotomi som får en helt sentral funksjon innenfor den romantiske estetikken, nemlig dikotomien mellom allegori og symbol. Über die Allegorie (1789) innleder Moritz på følgende måte:

In so fern eine Figur sprechend ist, in so fern sie bedeutend ist, nur in so fern ist sie schön. Dieß sprechende und Bedeutende muß aber in dem rechten Sinne genommen werden: Die Figur, in so fern sie schön ist, soll nichts bedeuten, und von nichts sprechen was außer ihr ist, sondern sie soll nur von sich selber, von ihrem inneren Wesen durch ihre äußere Oberfläche gleichsam sprechen, soll durch sich selbst bedeutend werden. Daher wird durch bloß allegorische Figuren, die Aufmerksamkeit, in Rücksicht auf die schöne Kunst, zerstreuet, und von der Hauptsache abgezogen. ... Das wahre Schöne besteht aber darin, daß eine Sache bloß sich selbst bedeute, sich selbst bezeichne, sich selbst umfasse, ein in sich vollendetes Ganze sei. ${ }^{6}$

Allegoriske fremstillinger - som Bunyans The Pilgrim's Progress og La Fontaines fabler - har ingen stor litterær verdi for Moritz, fordi de ikke har noen egen-verdi. Det at de

5 MORITZ, Karl Philipp: Versuch einer Vereinigung aller schönen Künste und Wissenschaften unter dem Begriff des in sich selbst Vollendeten. In: SCHRIMPF, Hans Joachim (Hrsg.): Schriften zur Ästhetik und Poetik. Berlin 1962, s. 153. Moritz foregriper her det som Kant, med hensyn til bedømmelsen av det skjønne, angir som smaksdommens tredje moment: „Schönheit ist Form der Zweckmäßigkeit eines Gegenstandes, sofern sie, ohne Vorstellung eines Zwecks, an ihm wahrgenommen wird“. KANT, Immanuel: Kritik der Urteilskraft. Berlin 1790, Erster Teil, Erster Abschnitt, Erstes Buch, §17.

6 MORITZ, Karl Philipp: Über die Allegorie. http://www.zeno.org/Literatur/M/Moritz,+Karl+Philipp/ Ästhetische+Schriften/Über+die+Allegorie, lest 08.06.2016 
ikke har noen egenverdi vil i denne sammenhengen si at de kun har en illustrerende funksjon, slik at tekstoverflaten umiddelbart peker ut over seg selv. Slike fremstillinger bryter med andre ord med Moritz' begrep om det fullendte kunstverket og den sanne skjønnheten på en grunnleggende måte.

Andre følger opp Moritz' ved å projisere hans begrep om det fullendte (intransitive og koherente) kunstverket inn i symbol-begrepet. Noen av de hyppigst refererte tekststedene når det gjelder det romantiske synet på forholdet mellom symbol og allegori finnes i Goethes Maximen und Reflexionen (nr. 279, 314, 1112, 1113). Uten å gå spesifikt inn i disse eller andre velkjente tekster som tematiserer dette forholdet i den aktuelle perioden, kan vi si at romantikkens begrep om det symbolske kunstverket tar opp i seg følgende seks elementer:

(1) I allegoriske kunstverk er overflaten gjennomsiktig. Verkene konstrueres med det for øyet å skulle illustrere allmenne idéer på en gjennomsiktig måte, og åpnes i den forstand opp mot en verden utenfor verket - mens overflaten har en egenverdi i symbolske kunstverk, og peker således ikke utover seg selv. Her gjenkjenner vi intransivitets-elementet fra Moritz' teorier.

(2) I og med at overflaten har en egenverdi i symbolske kunstverk, vil dens rent sanselige aspekter tre tydeligere frem. Det er ikke slik at det abstraherende intellektet innbys til å gripe slike allmenne idéer som allegoriske kunstverk er ment å illustrere - i stedet gis sansene en mulighet til å bevege seg langs overflaten, og dermed til å kunne dvele ved kunstverkets rent materielle kvaliteter.

(3) Denne overflaten fremstår også som meningsbærende. Den er konstruert rundt ett eller flere suggererende og fortettede bilder - symboler - som de enkelte delene peker i retning av på en organisk måte. Slik får det symbolske kunstverket en indre sammenheng. Her gjenkjenner vi harmoni-prinsippet eller koherens-elementet fra det som Moritz skriver om det fullendte kunstverk.

(4) Den meningen som skapes ved at de enkelte delene av kunstverket peker i retning av ett eller flere symboler, er ikke entydig. På grunn av symbolenes fortettede karakter, vil det symbolske kunstverket være mangetydig inntil det uuttømmelige.

(5) Symbolske kunstverk bærer ikke bare på et uuttømmelig meningspotensiale, de peker også i retning av det uutgrunnelige og det uutsigelige - med Goethes betegnelser: das Unerforschliche og das Unaussprechliche.

(6) I allegoriske kunstverk fremstilles det allmenne gjennom det særskilte - de særskilte bildene peker direkte mot allmenne idéer - mens det allmenne og det særskilte er sammenvevet i symbolske kunstverk.

Sammenfattende kan vi si at symbolske kunstverk er preget av følgende seks elementer: Intransitivitet, materialitet, koherens, polysemi, uutsigelighet, samt foreningen av det særskilte og det allmenne. Disse enkeltelementene er, foruten hos Goethe, helt eller delvis tilstede bl.a. hos Schelling, Solger, Coleridge og Carlyle. Dersom man i tillegg til de nevnte enkeltelementene skulle peke på en overordnet idé som konstituerer det romantiske symbolbegrepet, måtte det være enhets-idéen: Allegorien splitter, mens symbolet 
skaper enhet. Dermed kan de romantiske symbolteoriene ansees som et svar på den splittelses-erfaringen som preger den gryende moderniteten, og som innenfor filosofien tematiseres på radikal måte i den tyske idealismen: Splittelsen mellom subjekt og objekt, mellom ulike deler av subjektet, mellom subjekt og subjekt, mellom ulike samfunnsmessige verdisfærer, mellom menneske og natur.

\section{Romantiske tankefigurer i den „klassiske" strukturalismen}

I Cours de linguistique générale (1916) kaller Saussure språksystemets minste enhet for „tegn“ (signe), og han deler tegnet opp i en uttrykks- og innholdsside (signifiant/signifié). Dette åpner opp for to akser: En vertikal akse, hvor et uttrykk står i forhold til et innhold, en relasjon som resulterer i at tegnet gis en „betydning“ (signification); og en horisontal akse, hvor uttrykk står i relasjon til andre uttrykk og innhold til andre innhold innenfor ett og samme språksystem, relasjoner som gir tegnene en „verdi“ (valeur). Tegnenes „verdi“ er rent differensiell: De får sin verdi kun gjennom å være forskjellige fra andre tegn. At språksystemet er et system av forskjeller, beskriver Saussure som det mest fundamentale av alle lingvistiske saksforhold, i den forstand at verdien er primær i forhold til betydningen. „Sans elle [la valeur] la signification n'existerait pas“, skriver han således. ${ }^{7}$

Når det gjelder tegnenes referanse, er denne eliminert allerede i utgangspunktet av Saussure - som ledd i en innledende manøver av metodologisk art, foretatt for å kunne avgrense lingvistikkens studieobjekt. ${ }^{8}$ Mange av hans etterfølgere har på denne bakgrunn for det første forsøkt å fremstille språket som grunnleggende intransitivt. Ved på denne måten å ontologisere Saussures metodologiske blikk på språket, knytter de helt klart an til det første av de seks elementene som jeg lot inngå i det romantiske symbolbegrepet. I forlengelsen av dette lar man språkets mangel på ytre referanse kompenseres ved å fokusere på dets indre koherens. Dermed knytter man an til det tredje elementet i det romantiske symbolbegrepet, via Saussure. Og på dette punktet er man opplagt mer i pakt med Saussure selv enn det som er tilfellet i relasjon til intransitivitets-elementet; for språksystemets horisontale verdi-akse, og dermed dets indre koherens, defineres av Saussure eksplisitt som det mest fundamentale av alle lingvistiske saksforhold, som vi har sett.

Men selv om Saussure gjør relasjonen mellom ulike tegn til det primære, fokuserer han også på relasjonen mellom de enkelte tegnenes uttrykks- og innholdsside, dvs. på den vertikale betydnings-aksen. Saussures etterfølgere har vært preget av denne tvetydigheten i hans Cours, og generelt kan man si at et forhold som definerer Saussures etterfølgere blant post-strukturalistene, er at de rendyrker tegnenes relasjoner til hverandre, slik at koherens-elementet settes i sentrum - samtidig som man insisterer på språkets intransitivitet. Før vi går nærmere inn på post-strukturalismen, skal vi imidlertid kaste et blikk på kanskje den aller mest innflytelsesrike av Saussures etterfølgere innenfor den „klassiske“

7 SAUSSURE, Ferdinand de: Cours de linguistique générale. Èd. Critique preparée pat Tullio de Mauro. Paris 1981, del 2, kap. 4, §2.

8 Jfr. introd., kap. 3, §1: „'’est le point de vue qui crée l'objet.“ 
strukturalismen: Roman Jakobson - hvilket forutsetter at vi aller først må kikke litt på språkteoriene til en person som befant seg litt i utkanten av den egentlige strukturalismen, men som utgjorde en viktig inspirasjonskilde for Jakobson, nemlig Karl Bühler.

I pakt med Trubetzkoy og den funksjonalistiske lingvistikken, tar Bühler utgangspunkt i språkets primære funksjon, som han - fortsatt i pakt med funksjonalistene - hevder er av kommunikativ art. For at den kommunikative primærfunksjonen skal kunne realiseres, hevder Bühler, må språkbrukerne ha en viss „innstilling“ (Einstellung) til språklydene. Språkbrukerne må filtrere vekk de delene av lydmaterialet som ikke er semantisk relevante, dvs. som ikke bidrar til meningsproduksjonen. På bakgrunn av en abstraherende innstilling lærer språkbrukerne seg til å identifisere språksystemets fonemer, dvs. systemets minste betydningsdifferensierende enheter. Bühler bygger her direkte på Trubetzkoy. Språkbrukernes abstraherende innstilling muliggjør at språket kan brukes til å vise utover seg selv: Det kan „stå for noe annet“ - et forhold man i middelalderen betegnet med formularet aliquid stat pro aliquo: „Noe står for noe“. Dette formularet benytter også Bühler i sine teorier, for å illustrere at språkets tegn fundamentalt sett står i relasjon til en språk-ekstern virkelighet. Hans språktenkning bygger altså ikke på det intransitivitets-prinsippet som mange har gjort et stort nummer av innenfor den strukturalistiske tradisjonen.

I og med at språkets primære funksjon er å være et kommunikasjonsmiddel, er det imidlertid ikke nok at språktegnene står i relasjon til virkelige saksforhold: De må også være relatert til språkbrukerne. På denne bakgrunn deler Bühler språkets overordnede kommunikasjonsfunksjon inn i tre delfunksjoner:

Uttrykk (Ausdruck)

Representasjon el. fremstilling (Darstellung)

Appell (Appell)

Disse tre funksjonene er knyttet til kommunikasjonsaktens tre faktorer:

Sender

Saksforhold

Mottaker

Og de svarer til språktegnets tre sider:

Symptom (Indeks)

Symbol

Signal

Man får altså følgende nivåer:

Sender Saksforhold Mottaker

Uttrykk Representasjon Appell

Symptom Symbol Signal

Denne modellen summeres opp bl.a. i følgende passasje fra Bühlers Sprachtheorie fra 1934: „Es [das Sprachzeichen] ist Symbol kraft seiner Zuordnung zu Gegenständen und Sachverhalten, Symptom (Anzeichen, Indicium) kraft seiner Abhängigkeit vom Sender, 
dessen Innerlichkeit es ausdrückt, und Signal kraft seines Appells an den Hörer, dessen äußeres oder inneres Verhalten es steuert wie andere Verkehrszeichen." 9

Jakobson nyanserer Bühlers modell i sin kjente artikkel Linguistics and Poetics fra 1958, hvor kommunikasjonsaktens faktorer utvides fra tre til seks:

$\begin{array}{lll} & \text { Kontekst } & \\ \text { Sender } & \text { Meddelelse } & \text { Mottaker } \\ & \text { Kontakt } & \\ & \text { Kode } & \end{array}$

Disse faktorene knytter Jakobson til følgende funksjoner:

$\begin{array}{lll} & \text { Referensiell } & \\ \text { Emotiv (ekspressiv) } & \text { Poetisk } & \text { Konativ } \\ & \text { Fatisk } & \\ & \text { Metaspråklig } & \end{array}$

De tre faktorene sender, kontekst og mottaker tilsvarer Bühlers sender, saksforhold og mottaker; og den emotive, referensielle og konative funksjonen tilsvarer Bühlers uttrykks-, representasjons-og appellfunksjon. Alt etter hvilke faktorer språkbrukerne fokuserer på alt etter hvordan deres „innstilling“ varierer - aktiveres de tilhørende språkfunksjonene, og man får som resultat ulike typer av utsagn (ulike kommunikasjonsformer):

- Uttaler man rene påstander (dvs. utsagn som primært pretenderer å beskrive gitte saksforhold), fokuserer man på konteksten og den referensielle funksjonen aktiviseres. (,Jorden er rund“).

- Ved interjeksjoner fokuseres det på senderen, og den emotive funksjonen aktiviseres. („Au!“).

- Ved imperativer fokuseres det på mottakeren, og den konative funksjonen aktiviseres. („Drikk!“).

- Når man ønsker å etablere, avbryte eller forlenge kommunikasjonen, fokuseres det på kontakt-faktoren, og den fatiske funksjonen aktiviseres. (Ved etablering av kommunikasjonen, f.eks. for å oppnå kontakt med en attraktiv mann eller kvinne: „Hvor mye er klokken?“. For å forlenge kommunikasjonen: „Ja, ja“, „det er så“ osv.).

- Når sender eller mottaker trenger å kontrollere om de bruker samme kode - dvs. om de forstår hverandre - fokuserer man på kode-faktoren, og den metaspråklige funksjonen aktiviseres. („Skjønner du hva jeg mener?“).

- Dersom man utnytter språkets materialitet, dets rent lydlige kvaliteter - gjennom bruk av rim og rytme - fokuseres det på selve meddelelsen, og språkets poetiske funksjon aktiviseres. („Drammen er en drømmeby, sa Viggo Wam, og drakk en dram“).

Ved at man gjennom å ta i bruk språkets poetiske funksjon vender oppmerksomheten mot språket som sådan, overskygges språkets referensielle funksjon, hevder Jakobson,

9 BÜHLER, Karl: Sprachtheorie. Jena 1934, s. 28. 
og avstanden øker mellom tegn og objekt: Det poetiske språket tenderer mot intransitivitet. Dermed knytter han an til det romantiske symbolbegrepet, som vi ser. Jakobson trekker også inn sitt kjente skille mellom språkets seleksjons- og kombinasjonsakse. Det som skjer når språkets poetiske funksjon aktiviseres, er at likhetsprinsippet fra språkets seleksjonsakse projiseres over på kombinasjonsaksen, hevder han. F.eks. kan rim- og rytmemønstre ansees som likhetsrelasjoner langs kombinasjonsaksen. I poetisk språkbruk får således språkets materialitet en egenverdi. Dermed ser vi at Jakobson knytter an til enda et av de elementene som inngår i romantikkens symbolbegrep.

Julia Kristeva har gjort språkets materialitet til et hovedpoeng, særlig i sine analyser av modernistisk lyrikk, slik som i den monumentale monografien La révolution du langage poétique $^{10}$ - og med henne er vi på vei over i post-strukturalismen.

\section{Romantiske tankefigurer i post-strukturalismen}

Uten å gå nærmere inn på Kristeva, går vi direkte til den filosofiske hovedfiguren innenfor post-strukturalismen, nemlig Jacques Derrida, for å se om vi også hos ham kan etterspore romantiske tankefigurer.

Derrida innrømmer sin gjeld til Saussure, men samtidig gjennomfører han en dekonstruktiv lesning av Cours, dvs. en lesning som påviser hvordan en gitt tekst undergraver seg selv. Derrida arbeider således på tvers av Gadamers krav om at leseren må foregripe tekstens fullkommenhet (Vorgriff der Vollkommenheit), idet han i sin lesning av Cours spiller ut mot hverandre de to måtene som Saussure tematiserer tegnet på: som en enhet av uttrykk og innhold, og som en rent differensiell størrelse. Når tegnet fremstilles som en enhet bestående av en uttrykks- og en innholdsside, tenderer Saussure til å gi denne enheten en fastlagt og selvstendig mening. Denne tendensen har de fleste av Saussures etterfølgere forsterket, ved å ta fonologien som sitt utgangspunkt: For å finne frem til hvilke materielle lyd-nyanser som er betydnings-differensierende, må man ta utgangspunkt i en betydning som ansees som fastlagt på forhånd. Derrida rendyrker på sin side det differensielle momentet hos Saussure. Dette gjør han, i forlengelsen av Heidegger, som et ledd i en fundamental kritikk av den vestlige tenkningens „nærværs-metafysikk“. Denne kritikken kan i en tegnteoretisk kontekst formuleres på følgende måte:

Et tegn er ikke en selvstendig enhet som bærer med seg hele sin betydning. Betydningen er slik sett ikke „nærværende“ i selve tegnet. Et tegn er å anse som et punkt hvor andre tegn etterlater sine „spor“ (traces), og nye kontekster skaper stadig nye spor. Et tegn er altså ikke en selvidentisk enhet; det gis en stadig skiftende identitet, alt etter hvilke spor som kommer til syne. Tegnenes betydning er altså aldri endelig fastlagt. Idet man tror man har fanget den, glipper den unna. Denne stadige utsettelsen av betydningens nærvær - den ustoppelige glidningen fra nærvær til fravær, den stadige oppløsningen av tilsynelatende faste strukturer - forsøker Derrida å favne med en komprimert neologisme: différance. Med denne termen ønsker han for det første å fremvise det forholdet at

10 KRISTEVA, Julia: La révolution du langage poétique. Paris 1974. 
ethvert tegnsystem er å anse som et system av forskjeller; for det andre vil han fremheve at ethvert system er grunnleggende ustabilt, altså at det ikke bare er en rigid struktur, hvor alle elementene har sin faste plass i forhold til hverandre, men at det er i stadig bevegelse; for det tredje (og dette er kanskje hovedpoenget) vil han påpeke at tegnenes betydning glipper idet vi tror vi har grepet den. La meg forsøke å presisere:

Différance uttales akkurat som différence. Gjennom denne siste termen, som den første bærer med seg som ett av flere elementer, er det selve forutsetningen for meningsproduksjonen som tematiseres: tegnenes forskjellighet innenfor rammen av et tegnsystem. Ved at $e$ byttes ut med $a$, fremstår différance-termen som et verbalsubstantiv, avledet av verbet différer, som betyr å „være forskjellig fra“ (endelsen -ance brukes på fransk til å konstruere verbalsubstantiver), og derved tematiseres meningsproduksjonen som en akt, som noe som stadig gjentar seg på nye måter. Men verbet différer har også en annen betydning: å „utsette“. Dermed tematiseres meningsproduksjonens radikalt produktive karakter. For i og med at meningsproduksjonen er en akt som stadig gjentar seg på nye måter, slik at stadig nye spor etterlates i tegnene, vil tegnene aldri kunne tilskrives noen endelig betydning. Betydningens nærvær vil alltid utsettes. Resultatet er at alle tegn og tegnsekvenser vil være mangetydige inntil det uuttømmelige.

Denne tematikken er det mange som har ført videre fra Derrida. Men som alle vet, er ikke dette noen ny tematikk - bl.a. ser vi klare paralleller til romantikkens symbolteorier. Mangetydighet er et av de elementene som inngår i det romantiske symbolbegrepet, som vi husker - og mangetydighet, eller polysemi, har generelt blitt et viktig begrep innenfor post-strukturalismen, ikke bare hos Derrida.

La oss avslutningsvis gå til en teoretiker som gjennom 1980-tallet fikk en like høy status som Derrida innenfor litteraturvitenskapelige miljøer: Paul de Man. Han er en av de få post-strukturalistene som eksplisitt knytter an til romantikkens symbolteorier, og som dermed har bidratt til å synliggjøre i hvilken grad man innenfor den strukturalistiske tradisjonen har trukket veksler på romantisk tankegods. I et essay fra 1969, „The Rhetoric of Temporality“, setter han således allegorien opp mot symbolet, slik Moritz og romantikerne gjør - men han snur om på rangordningen: Allegorien fremviser det ikkeidentiske i relasjonen mellom språktegnets uttrykk og innhold, og - analogt - mellom ordene og tingene; den minner oss på den splittelsen som konstituerer språket og vårt virkelighetsforhold. Det samme gjelder en annen språklig figur: ironien. Fordi de fremhever distansen og splittelsen, og dermed representerer en figurlig anskueliggjøring av menneskets eksistensielle grunnvilkår, gis allegorien og ironien status som språkets master tropes av de Man. Det romantiske symbolet, som etter sigende tildekker den splittelsen som preger mennesket som et språklig vesen, fremstilles på sin side som en tilslørende „forsoningstrope“.

Paul de Mans fokus på splittelsens og distansens uomgjengelighet er beslektet med den filosofiske tilnærmingen i Adornos „negative dialektikk“, hvor vi bl.a. finner begrepet om det ikke-identiske:

[...] eine Dialektik nicht der Identität sondern der Nichtidentität. Es handelt sich um den Entwurf einer Philosophie, die nicht den Begriff der Identität von Sein und Denken voraussetzt und auch 
nicht in ihm terminiert, sondern die gerade das Gegenteil, also das Auseinanderweisen von Begriff und Sache, von Subjekt und Objekt, und ihre Unversöhntheit, artikulieren will. ${ }^{11}$

Det hviler et tragisk, ikke-forsonende skjær over både Adorno og de Mans teorier. Begge ser ut til å være preget av en slags eksistensiell splittelses-erfaring, en erfaringstype som i realiteten finner sin første historiske form nettopp i romantikken. En slik erfaring kan møtes og blir møtt på ulike vis:

Den første generasjonen av romantikere i England (Wordsworth, Coleridge) og innenfor det tysk-språklige området (Jena-kretsen) hadde i utgangspunktet en overveiende positiv innstilling til den franske revolusjonen og store deler av opplysningsprosjektet. Men etter hvert som langvarige revolusjons- og napoleonskriger satte sitt preg på Europa, og den industrielle revolusjonen bidro til sosialt oppbrudd og naturødeleggelser både i England - særlig der - og på kontinentet, vendte de samme førstegenerasjonsromantikerne seg bort fra sin ungdommelige radikalitet og begynte å lese både den franske revolusjonen og den påfølgende samfunnsutviklingen inn i en krisefortelling med fokus på fragmentering, fremmedfølelse og splittelse. Kriseerfaringen svarte man på ved å ta tilflukt til overgripende instanser som man forestilte seg kunne bidra til en form for helhetsskapende forsoning, slik som religion, nasjon og tradisjon. Og ikke minst ble denne kriseerfaringen bearbeidet kunstnerisk. Friedrich Schlegel, som var en drivende kraft i den tyske tidligromantikken slik den utfoldet seg i Jena fra siste halvdel av 1790-tallet, eksemplifiserer denne utviklingen på en karakteristisk måte:

I begynnelsen av sin karriere gir Schlegel tydelig uttrykk ikke bare for sin revolusjonsbegeistring, men også for en slik religionskritisk holdning som mange opplysningstenkere hadde utviklet gjennom 1700-tallet. Han stiller seg således undrende til teologen Friderich Schleiermachers religiøse synspunkter når sistnevnte blir kjent med Schlegel og hans venner i Jena-kretsen. Schleiermacher forfatter imidlertid et forsvar for religionens betydning i menneskelivet som et svar på den religionsskepsisen som preger Jena-miljøet, og dette forsvarsskriftet ${ }^{12}$ er med på å føre bl.a. Schlegel inn i den religiøse folden, først som lutheraner, og fra 1808 som katolikk, da Schlegel og hans ektefelle Dorothea blir to av et betydelig antall konvertitter blant tyskspråklige romantikere. Schlegel ender etter hvert opp i Wien, der han etter Wienerkongressen blir nært knyttet til fyrst Metternich og den politiske makten, etter at han i 1814 hadde blitt utnevnt til ridder av den pavelige Kristusorden. Han grunnlegger dessuten det katolske, sterkt konservative tidsskriftet Concordia i 1820. Friedrich Schlegel går altså en vei fra ungdommelig radikalitet til politisk og religiøs konservatisme som er ganske så representativ for den første generasjonen av romantikere.

Nettopp Friedrich Schlegels skrifter vies en bred omtale i det nevnte essayet av de Man, „The Rhetoric of Temporality“, i forbindelse med hans utlegning av ironi-figuren. Og her er det den unge Schlegel som settes i fokus, dvs. en Schlegel som ennå ikke har

11 ADORNO, Theodor W.: Vorlesung über Negative Dialektik. Hrsg. v. Tiedemann, Rolf. Frankfurt a.M. 2003, s. 15 f.

12 SCHLEIERMACHER, Friedrich: Über die Religion: Reden an die Gebildeten unter ihren Verächtern. Berlin 1799. 
søkt tilflukt i konserverende religiøse og politiske ideologier. For det er i denne fasen han utvikler sitt ironibegrep, og det er her han utvikler en litterær praksis hvor ironien til slutt bringer ham inn en svimlende bevegelighet, slik Schlegel selv gir uttrykk for i det berømte essayet „Über die Unverständlichkeit“, som de Man siterer en lang passasje fra. Schlegel skriver:

Im allgemeinen ist das wohl die gründlichste Ironie der Ironie, daß man sie doch eben auch überdrüssig wird, wenn sie uns überall und immer wieder geboten wird. Was wir aber hier zunächst unter Ironie der Ironie verstanden wissen wollen, das entsteht auf mehr als einem Wege. Wenn man ohne Ironie von der Ironie redet, wie es soeben der Fall war; wenn man mit Ironie von einer Ironie redet, ohne zu merken, daß man sich zu eben der Zeit in einer andren viel auffallenderen Ironie befindet; wenn man nicht wieder aus der Ironie herauskommen kann, wie es in diesem Versuch über die Unverständlichkeit zu sein scheint; wenn die Ironie Manier wird, und so den Dichter gleichsam wieder ironiert; wenn man Ironie zu einem überflüssigen Taschenbuche versprochen hat, ohne seinen Vorrat vorher zu überschlagen und nun wider Willen Ironie machen muß, wie ein Schauspielkünstler der Leibschmerzen hat; wenn die Ironie wild wird, und sich gar nicht mehr regieren läßt. Welche Götter werden uns von allen diesen Ironien erretten können? das einzige wäre, wenn sich eine Ironie fände, welche die Eigenschaft hätte, alle jene großen und kleinen Ironien zu verschlucken und zu verschlingen, daß nichts mehr davon zu sehen wäre, und ich muß gestehen, daß ich eben dazu in der meinigen eine merkliche Disposition fühle..$^{13}$

Etter først på en fornøyelig måte å ha beskrevet ironiens hvileløse karakter, ser det ut som om Schlegel avslutningsvis i denne passasjen kommer til et punkt hvor han leter etter en vei ut av en slik uendelig selvoppløsende prosess som han har brakt seg inn i gjennom sin dyrking av en ironi som aldri opphører å ironisere over seg selv. Dette essayet - med all sin lekne ironi - kan dermed paradoksalt nok leses som et frempek mot den litt eldre Schlegels posisjonering i et religiøst og ideologisk landskap som gir ham fast grunn under føttene.

Schlegel kan gjennom sin intellektuelle utvikling dermed sies å ha gitt Hegel rett i sistnevntes vurdering av den schlegelske ironi som uttrykk for en umoden bevissthet som flykter unna enhver forpliktende relasjon til alt som overskrider ens egen suverene subjektivitet. ${ }^{14}$ Et slikt synspunkt er i pakt med en slik lesning av Schlegels verk som

13 SCHLEGEL, Friedrich: Ûber die Unverständlichkeit. http://www.zeno.org/Literatur/M/ Schlegel,+Friedrich/Ästhetische+und+politische+Schriften/Über+die+Unverständlichkeit, lest 13.06.2016.

14 „Und nun erfaßt sich diese Virtuosität eines ironisch-künstlerischen Lebens als eine göttliche Genialität, für welche alles und jedes nur ein wesenloses Geschöpf ist, an das der freie Schöpfer, der von allem sich los und ledig weiß, sich nicht bindet, indem er dasselbe vernichten wie schaffen kann. [...]Die nächste Form dieser Negativität der Ironie ist nun einerseits die Eitelkeit alles Sachlichen, Sittlichen und in sich Gehaltvollen, die Nichtigkeit alles Objektiven und an und für sich Geltenden. Bleibt das Ich auf diesem Standpunkte stehen, so erscheint ihm alles als nichtig und eitel, die eigene Subjektivität ausgenommen, die dadurch hohl und leer und die selber eitle wird." HEGEL, G. W. F: Werke in 20 Bänden mit Registerband, Bd. 13: Vorlesungen über die Ästhetik I. Frankfurt a. M. 1970, s. 95f. 
bl.a. Peter Szondi leverer ${ }^{15}$, men som Paul de Man polemiserer mot i „The Rhetoric of Temporality“, dvs. en lesning som ser på ironi som „a preliminary movement toward a recovered unity“, og som gjør ironien til „the prefiguration of a future recovery“. ${ }^{16}$ I en anti-hegeliansk gest forsøker de Man, som Adorno i sin negative dialektikk, å fremheve den ikke-totaliserende, hvileløst bevegelige tanke som et ideal - et ideal som Freidrich Schlegel målbærer i sine tidlige, ironi-pregede skrifter.

Disse skriftene kan, med Hegels ord, sies å uttrykke en form for „ulykkelig bevissthet“, en bevissthet som går på tomgang i sine gjentatte ironiske loops, og som derfor aldri vil kunne inngå i forpliktende relasjoner til noe utenfor seg selv. Paul de Man kan ansees som en moderne, poststrukturalistisk representant for en slik måte å forholde seg til verden på. I hans tilfelle er den ulykkelige bevisstheten formet innenfor rammene av en slik tenkning som springer ut av etterkrigstidens linguistic turn, som man noe uærbødig kanskje kan kalle en lingvistisk „fetisjisme“. Når alle typer av menneskelige uttrykk blir ansett som analoge til språklige uttrykk, og når alle kulturuttrykk som mennesket skaper derfor hevdes å kunne analyseres og forståes ved hjelp av teorier og metoder som er utviklet innenfor en lingvistisk ramme, foretar man i realiteten en reduksjonistisk manøver som gjør at man ikke tar på alvor mangfoldet i menneskets måter å forholde seg til verden på. Når språklig erkjennelse gjøres til normen, vil man dessuten bli tatt av en form for resignasjon hva angår muligheten til å gripe verden som sådan dersom man samtidig vektlegger splittelsen mellom språk og virkelighet, slik bl.a. de Man gjør. Resultatet blir en altomfattende, konturløs konstruktivisme, og det var nettopp dette poststrukturalismen munnet ut i (til tross for at termen „dekonstruksjon“ ofte brukes om poststrukturalistiske lesemåter).

Den klassiske strukturalismen var i utgangspunktet mer beskjeden i sine pretensjoner, idet man der fulgte opp Saussures rent metodologiske definisjon av sitt studieobjekt. Etter at man fulgte opp Saussures antydning i Cours om å utvikle en allmenn semiologi, gikk imidlertid strukturalismen ut over sine lingvistiske enemerker og føyde seg inn i etterkrigstidens altomfattende linguistic turn. Samtidig fikk man økte teoretiske ambisjoner i retning av det filosofiske, noe som ble ytterligere forsterket innenfor poststrukturalismen, som bidro til en ontologisering av den splittelsen mellom språk og virkelighet som altså for Saussure kun var resultatet av en metodologisk avgrensning hvorigjennom språksystemet kunne identifiseres som et selvstendig studieobjekt. Gjennom sin insistering på menneskets manglende evne, qua språkvesen, til å favne verden, ender Paul de Man og andre poststrukturalister opp som desillusjonerte og rastløse arvinger til den klassiske strukturalismen. De lar mennesket kastes hvileløst fra spor til spor i en rekke av tegn, utlevert til en prosess hvor betydningen aldri kan gripes fullt ut (Derrida); og de henviser subjektet til stadig nye posisjoner i språket ved å gjøre ironiens selvoppløsende bevegelighet til et ideal (de Man).

15 SZONDI, Peter: „Friedrich Schlegel und die romantische Ironie“. In: Satz und Gegensatz. Frankfurt a. M. 1964

16 DE MAN, Paul: The Rhetoric of Temporality. In: Blindness and Insight, 2nd. ed. London 1983, s. 187228 (her s. 219). 
De fremstår også som romantikkens desillusjonerte arvinger. For, som jeg har forsøkt å vise, trekker man med seg tankefigurer fra romantikken - bl.a. elementer fra det romantiske symbolbegrepet - innenfor både den klassiske strukturalismen og poststrukturalismen. Det er imidlertid ett element i det romantiske symbolbegrepet som man, med sitt lingvistiske fokus, ikke tematiserer, nemlig det uutsigelige, og dermed blir man stående og stange hodet mot språkets yttergrenser. I romantikken er refleksjonen rundt det uutsigelige noe som gjenfinnes i svært mange kontekster, og ikke bare i relasjon til symbolbegrepet. Det fremheves som en svært sentral komponent i både natur- og kunstopplevelser, samt i religiøse sammenhenger, hvor det ofte (for eksempel hos Schleiermacher) knyttes sammen med opplevelsen av det uendelige.

Den opptattheten av det sublime, som vokste frem parallelt med poststrukturalismen, gjør imidlertid nettopp det uutsigelige til et hovedtema. Det kanskje mest kjent eksemplet på dette, finner vi hos Jean-François Lyotard, som - ved å gripe tilbake til Kant og hans begrep om det sublime - forsøker å vise hvordan modernistisk kunst representerer et paradoksalt forsøk på å representere det som ikke lar seg representere. ${ }^{17}$ Lyotard er, typisk nok, mest fokusert på billedkunst når han skriver om det sublime, og slik sett peker han - som romantikerne - i retning av det mangfoldige repertoaret av uttrykksmidler som mennesket råder over, og som ikke - uten å reduseres - lar seg gripe ved hjelp av teorier og kategorier som er utarbeidet innenfor en språkteoretisk ramme. Det sublime peker ut av språket, mot det uutsigelige.

\section{Litteratur}

ADORNO, Theodor W. (2003): Vorlesung über Negative Dialektik. Hrsg. v. Tiedemann, Rolf. Frankfurt a.M., s. $15 f$.

ASHLEY-COOPER, Anthony, 3rd Earl of Shaftesbury: Soliloquy: Or, Advice to an Author. http:// oll.libertyfund.org/titles/811\#Shaftesbury_5987_360, lest 09.06.2016.

BÜHLER, Karl (1934): Sprachtheorie. Jena.

DE MAN, Paul (1983): The Rhetoric of Temporality. In: Blindness and Insight, 2nd. ed. London, s. $187-228$.

GOETHE, J. W. (2006): Maximen und Reflexionen. München.

HEGEL, G. W. F. (1970): Werke in 20 Bänden mit Registerband, Bd. 13: Vorlesungen über die Ästhetik I. Frankfurt a. M.

JAKOBSON, Roman (1960): Closing Statements: Linguistics and Poetics. In: SEBEOK, Thomas A. (ed.): Style In Language. Cambridge, Mass., s. 350-377.

JAKOBSON, Roman (1956): Two Aspects of Language and Two Types of Aphasic Disturbances. In:

JAKOBSON, R. \& HALLE, M.: Fundamentals of Language. The Hague. KANT, Immanuel (1790): Kritik der Urteilskraft. Berlin.

17 Se for eksempel LYOTARD, Jean-François: Reponse à la question: Qu'est-ce que le postmoderne? In: Critique 38, 1982, s. 357-367: „c'est dans l'esthétique du sublime que l'art moderne (y compris la littérature) trouve son ressort, et la logique des avant-gardes ses axiomes (...) [les] avant-gardes picturales ... se consacrent à faire allusion à l'imprésentable par des présentations visibles“ (s. 363f). Lyotard representerer altså med sine skrifter om det sublime en helt annen teoretisk tilnærming enn det vi finner innenfor poststrukturalismen, selv om han av og til blir grupperert sammen med denne. 
KRISTEVA, Julia (1974): La révolution du langage poétique. Paris.

LYOTARD, Jean-François (1982): Reponse à la question: Qu'est-ce que le postmoderne? In: Critique 38, s. 357-367.

MORITZ, Karl Philipp: Ûber die Allegorie. http://www.zeno.org/Literatur/M/ Moritz,+Karl+Philipp/ Ästhetische+Schriften/Über+die+Allegorie, lest 08.06.2016.

MORITZ, Karl Philipp (1962): Versuch einer Vereinigung aller schönen Künste und Wissenschaften unter dem Begriff des in sich selbst Vollendeten. In: SCHRIMPF, Hans Joachim (Hrsg.): Schriften zur Ästhetik und Poetik. Berlin.

PANOFSKY, Erwin (1955): The Life and Art of Albrecht Dürer. Princeton, New Jersey.

SAUSSURE, Ferdinand de (1981): Cours de linguistique générale. Èd. Critique preparée par Tullio de Mauro. Paris.

SCHLEGEL, Friedrich: Ûber die Unverständlichkeit. http://www.zeno.org/Literatur/M/ Schlegel,+Friedrich/Ästhetische+und+politische+Schriften/Über+die+Unverständlichkeit, lest 13.06.2016.

SCHLEIERMACHER, Friedrich (1799): Über die Religion: Reden an die Gebildeten unter ihren Verächtern. Berlin.

SZONDI, Peter (1964): Friedrich Schlegel und die romantische Ironie. In: Satz und Gegensatz. Frankfurt a. M.

TODOROV, Tzvetan (1977): Théories du symbole. Paris.

TRUBETZKOY, Nicolai S. (1939): Grundzüge der Phonologie. Praha.

Otto Martin Christensen, dr. art. / otto.christensen@hit.no

Associate Professor of Philosophy

University College of Southeast Norway, 3800 Bø i Telemark, Norway 
